\title{
Diversity and Functionality of Seed Vectored Bacterial Endophytes in Different Cultivars of Triticum Aestivum L. Across Ecological Boundaries
}

\section{Jogdande SaiPrasad}

ICAR-Indian Agricultural Research Institute

Archna Suman ( $\sim$ archsuman@yahoo.com )

ICAR-Indian Agricultural Research Institute

\section{B. Ramakrishnan}

ICAR-Indian Agricultural Research Institute

\section{K. Aswini}

ICAR-Indian Agricultural Research Institute

\section{Research Article}

Keywords: ndophytes, Seeds, Diversity, Wheat, Plant Growth promotion, Agroclimatic Zones

Posted Date: October 28th, 2021

DOI: https://doi.org/10.21203/rs.3.rs-989999/v1

License: @ (i) This work is licensed under a Creative Commons Attribution 4.0 International License. Read Full License 


\section{Abstract}

The endophytic microbial communities of plant seeds are either early or late colonizers, from the vascular system and stigma of mother plants or through contact from the environmental niches. Microbial communities get established in the plant progenies, particularly seeds, by vertical or horizontal transmission. The composition of seed microbiome determines the type of microbial associations, ranging from mutualism to pathogenicity with the emerging plants and also, the environmental conditions have a significant effect on their diversity.

Wheat associated microbiota, especially rhizobacteria and endophytes from different plant organs possess competencies for plant growth promotion, and mitigation of abiotic and biotic stress. Improved yield and adaptation, as well as sustained wheat production across different ecologies necessitate the microbiome basis for understanding the genotype-environment $(\mathrm{G} \times \mathrm{E})$ interactions. Hence,we investigated the diversity and functions of culturable endophytes from different ecological conditions on seed germination and the growth and fitness of plants. The core culturable microbiome members associated with seeds were identified, and evaluated for their potential for application and ensuing colonization in wheat plants. The diversity indices such as Shannon diversity $(\mathrm{H})$, Chao1, Simpson's reciprocal index and Species evenness $(\mathrm{J})$ were generally highest in the PZ, followed by the NHZ. Likewise,this study showed that the genotypes play a profound role in their diversity, with variations in the hydrolytic enzyme production, plant growth promotion and priority effects on seedling colonization of wheat. The potential for hydrolytic enzyme production also suggest the multifarious mechanisms mediated by these endophytic bacteria for colonization and antagonism against plant pathogens.

\section{Introduction}

Plants have various microorganisms internally as endophytes, living as the commensals and accomplishing several beneficial functions to the hosts but without their presence seen. The endophytes and other microbiota associated with the surfaces of the host plants as the 'holobiont,' determine growth, differentiation, development, health, and productivity. The endophytes can explicitly contribute to seed germination and growth before other types of microbial associations establish in the emerging plants (Berg et al., 2015). The gymnosperm and angiosperm plants (the spermatophytes) give out seeds that germinate to produce new plants, and all the seeds harbour endophytes, just like roots, leaves, and other plant organs. The transfer of endophytes to seeds may occur through the environmental niches, and the vascular connections from different plant organs. Besides, the gametes or the reproductive meristems may also provide endophytes for the embryo- and endosperm colonization (Malfanova et al., 2013). Thus, the endophytic communities of seeds are either the early colonizers from the vascular system and stigma of mother plants or the late colonizers through contact from the environmental niches.

Seed transmission of microorganisms from one generation to another is known for a long, evidently from the seed-borne pathogens (Johnston-Monje et al., 2016). In different organs of plant progenies including seeds, endophytic microbial communities may establish either through vertical or horizontal transmission (James et al., 2002). The co-evolutionary processes suggest that the vertically transmitted microbiota, through direct transfer from parents to progenies, may have the conserved endophyte properties with active involvement in the preservation and germination of seeds (Truyens et al., 2014 \& 2015). During seed germination, the endophytes aid in nutrient acquisition by plants and synthesize plant hormones addedly (Xu et al., 2014). The endophytic metabolites, such as lipopeptides, possess antifungal activities (Gagne-Bourgue et al., 2013). Herrera et al. (2016) reported that the endophytic communities of wheat seeds had members of Paenibacillus and Pantoea with potentials for plant growth promotion and biocontrol activities against Fusarium graminearum. The wheat associated microbiota, especially rhizobacteria and endophytes from different plant organs possess competencies for plant growth promotion, and mitigation of drought, acidity, salinity or low temperature (Mishra et al., 2011; Verma et al., 2013 \& 2014).

Wheat is cultivated under different agro-ecological conditions worldwide. In India, the zones are classified based on soil characteristics, rainfall patterns, temperature, and terrain as Northern Hill Zone (NHZ), North-Western Plains Zone (NWPZ), North Eastern Plains Zone (NEPZ), Central Zone (CZ), Peninsular Zone (PZ), and Southern Hill Zone (SHZ) (Trethowan et 
al.,2018; Table 1). The assemblages of microbiota in wheat seeds from these ecological conditions are poorly investigated. Information on the seed microbial assemblages (seed microbiome) will recognize the genotype-specific members and the variations in their compositions and functional capabilities due to the ecological conditions. In rice plants, most seed endophytes colonize shoots while some strains move to the rhizosphere (Mano et al., 2006). Truyens et al. (2015) suggested that the vertical transmission of microbiota ensures the 'continuity of partnership' with the host plants. The compositions of seed microbiome determine the type of microbial associations, ranging from mutualism to pathogenicity with the emerging plants.

The genetic relationships among wheat varieties and environments are a constituent factor for yield evaluation of new genotypes and identifying locations as the yield predictors across ecological conditions under the varietal release systems all over the world(Trethowan et al., 2018). Improved yield and adaptation, and sustained production of wheat across different ecologies necessitate the microbiome basis for understanding the genotype-environment $(\mathrm{G} \times \mathrm{E})$ interactions. In this present study, we hypothesized that the culturable endophytic communities of seeds differed in the wheat genotypes adapted to different agro-ecological zones. This study examined the functions of culturable endophytes on seed germination and the growth and fitness of plants. The members of endophytes from the genotypes adapted to different agro-ecological zones are investigated to identify the core culturable microbiome members that are associated with seeds, and to evaluate the potential for their application and the ensuing colonization in wheat plants.

\section{Results}

\section{Abundance of culturable endophytic bacteria in wheat seeds}

The mean population densities of culturable, bacterial endophytes ranged from $2.79 \pm 0.05$ to $5.19 \pm 0.06 \log ^{C F U ~ g}{ }^{-1} \mathrm{~d}$.w. seed, with variations which could be attributed to the type of medium tested and the wheat cultivation zones. The total endophytic bacterial population densities were the least in the $\mathrm{CZ}$ with the use of nutrient agar (NA) medium while the highest was in the NHZ with the use of newly designed, Wheat Flour-based Agar (WFA) medium (SaiPrasad, et al. 2020; Table 2). The zonal influences were apparently lesser on the total population densities, when cultured using the Trypticase Soy Agar (TSA) medium. In general, the culturable endophytic bacterial populations were lesser in the seeds sampled from the $\mathrm{CZ}, \mathrm{PZ}$, and SHZ than those from the NEPZ, NHZ, and NWPZ. The culturability of bacterial endophytes differed among the media used and additionally, the abundance of these bacteria was typically more in the seeds from the NEPZ, followed by the NWPZ and $\mathrm{NHZ}$. On the basis of morphometric analyses including morphology, size, and pigmentation of colonies, a total of 220 endophytes (43, 40, 38, 28, 34 and 37 from the NWPZ, NEPZ, NHZ, CZ, PZ and SHZ, respectively) were selected for biochemical and phylogenetic investigations.

\section{Phenotyping and Phylotyping of Wheat Seed Endophytic Bacteria}

The phenotyping of Wheat Seed Endophytic Bacteria (WSEB) which was performed by examining their growth at different temperatures ( $\left.4-40^{\circ} \mathrm{C}\right), \mathrm{pH}$ (3 to 10), salt concentrations (5-15\%), and polyethylene glycol concentrations (PEG 6000, 10-15\%) showed considerable variations in their potentials (Supplementary Fig. 1).

The most predominant, distinctly different isolates from each zone were further subjected to the phylotyping by sequencing the partial 16S rRNA genes. The accession numbers of the NCBI GenBank for the phylotypes (46) were MT184815MT184857(Supplementary Fig. 2). The diversity indices of these phylotypes in the wheat cultivation zones showed marginal differences (Table 2). The Shannon diversity $(H)$ value was the highest in the PZ while those of Chao1 and Simpson's reciprocal indices were the lowest in the NEPZ. The values of species evenness were higher in the NHZ, followed by the NEPZ. Irrespective of these minor differences in the diversity indices, seeds were enriched with three bacterial phyla (i.e., Firmicutes, Actinobacteria and Proteobacteria with the distribution ratios of $87.0 \%, 6.5 \%$ and $6.5 \%$, respectively) (Supplementary Fig. 3). In all the six wheat cultivation zones, the members of Bacillus belonging to the Phylum Firmicutes were predominant and the 
numbers of other identified species were about three each in Actinobacteria and Proteobacteria.The niche specific species were Bacillus cereus in the NWPZ, Saccharibacillussacchari in the NEPZ, B. paranthracis in the NHZ, B. australimaris in the $\mathrm{PZ}$ and $B$. aerius in the $\mathrm{SHZ}$, respectively (Fig. 1). The phylogenetic relationships among the identified bacterial species showed that the endophytes were more diverse in the NWPZ than in other zones.

Table 1

Major wheat cultivation zones with the characteristic features of area, productivity, number of varieties released and constraints

\begin{tabular}{|c|c|c|c|c|c|c|}
\hline $\begin{array}{l}\text { Wheat } \\
\text { cultivation } \\
\text { zone }\end{array}$ & $\begin{array}{l}\text { Area } \\
\text { (Million } \\
\text { ha) }\end{array}$ & $\begin{array}{l}\text { Productivity } \\
\text { (t/ha) }\end{array}$ & $\begin{array}{l}\text { No. of } \\
\text { varieties } \\
\text { notified }\end{array}$ & Major varieties & Number of samples & \\
\hline $\begin{array}{l}\text { Norther } \\
\text { Hills Zone } \\
\text { - NHZ } \\
\left(31^{\circ} 06^{\prime}\right. \\
12^{\prime \prime} \mathrm{N}: 77^{\circ} \\
\left.10^{\prime} 20^{\prime \prime} \mathrm{E}\right)\end{array}$ & 0.8 & 16.6 & 36 & $\begin{array}{l}\text { VL 616, HS 240, HPW } \\
251, \text { HS 507, VL } 907, \\
\text { VL 892, HPW } 349\end{array}$ & $\begin{array}{l}\text { Low temperature, Moisture } \\
\text { stress, Low soil fertility, frost } \\
\text { damage }\end{array}$ & 15 \\
\hline $\begin{array}{l}\text { North } \\
\text { Western } \\
\text { Plains } \\
\text { Zone- } \\
\text { NWPZ } \\
\left(28^{\circ} 36^{\prime}\right. \\
50^{\prime \prime} \mathrm{N}: 7^{\circ} \\
\left.12^{\prime} 32^{\prime \prime} \mathrm{E}\right)\end{array}$ & 11.6 & 39.4 & 80 & $\begin{array}{l}\text { HD 2009, HD 2285, HD } \\
2329, \text { PBW 343, DBW } \\
17, \text { HD 2967, HD } 3086\end{array}$ & $\begin{array}{l}\text { High fertilizer dose, Decline of } \\
\text { water table, intensive tillage, } \\
\text { terminal heat stress }\end{array}$ & 18 \\
\hline $\begin{array}{l}\text { North } \\
\text { Eastern } \\
\text { Plains } \\
\text { Zone - } \\
\text { NEPZ } \\
\left(25^{\circ} 51^{\prime}\right. \\
39^{\prime \prime} \mathrm{N}: 85^{\circ} \\
\left.46^{\prime} 56^{\prime \prime} \mathrm{E}\right)\end{array}$ & 10.5 & 25.1 & 55 & $\begin{array}{l}\text { UP 262, HUW 234, HD } \\
2967, \text { DBW 14, DBW } \\
39, \text { LBW 38, K 0307, K } \\
\text { 1006, HD 2733, NW } \\
5054\end{array}$ & $\begin{array}{l}\text { High temperature, Moisture } \\
\text { stress, Micronutrient } \\
\text { deficiencies }\end{array}$ & 12 \\
\hline $\begin{array}{l}\text { Central } \\
\text { Zone - CZ } \\
\left(22^{\circ} 43^{\prime}\right. \\
31^{\prime \prime} \mathrm{N}: 75^{\circ} \\
\left.51^{\prime} 55^{\prime \prime E}\right)\end{array}$ & 5.2 & 24.1 & 56 & $\begin{array}{l}\text { Jairaj, Sujata, Swati, HI } \\
\text { 1544, HI 8498, MP } \\
\text { 4010, GW 322, GW 366, } \\
\text { GW } 273\end{array}$ & $\begin{array}{l}\text { Moisture stress, High } \\
\text { temperature }\end{array}$ & 6 \\
\hline $\begin{array}{l}\text { Peninsular } \\
\text { Zone- PZ } \\
\left(20^{\circ} 04^{\prime}\right. \\
59^{\prime \prime} \mathrm{N}: 74^{\circ} \\
\left.07^{\prime} 00^{\prime \prime} \mathrm{E}\right)\end{array}$ & 1.6 & 29.8 & 57 & $\begin{array}{l}\text { HD 2189, DWR 162, NI } \\
5439, \text { NIAW 917, MACS } \\
6222\end{array}$ & $\begin{array}{l}\text { High temperature, Imbalanced } \\
\text { fertilizer usage, Light soils, } \\
\text { Moisture stress }\end{array}$ & 12 \\
\hline $\begin{array}{l}\text { Southern } \\
\text { Hill Zone- } \\
\text { SHZ } \\
\left(11^{\circ} 22^{\prime}\right. \\
12^{\prime \prime} \mathrm{N}: 06^{\circ} \\
\left.48^{\prime} 00^{\prime \prime} \mathrm{E}\right)\end{array}$ & 0.1 & 10.1 & 9 & $\begin{array}{l}\text { NP 200, HW 5216, HW } \\
\text { 1085, HUW 318, HW } \\
517, \text { HD } 2135\end{array}$ & Moisture stress, Acidic soils & 9 \\
\hline
\end{tabular}


Table 2

Population densities of culturable endophytic bacteria and the diversity indices of phylotypes of predominant cultural isolates

\begin{tabular}{|c|c|c|c|c|c|c|c|}
\hline \multirow[t]{3}{*}{ Wheat cultivation zone } & \multirow{2}{*}{\multicolumn{3}{|c|}{$\begin{array}{l}\text { Repertoire of cultures } \\
\text { Medium used }\end{array}$}} & \multicolumn{4}{|c|}{ Diversity indices of phylotypes } \\
\hline & & & & \multirow{2}{*}{$\begin{array}{l}\text { Shannon- } \\
\mathrm{H}\end{array}$} & \multirow{2}{*}{$\begin{array}{l}\text { Simpson- } \\
\text { D }\end{array}$} & \multirow[t]{2}{*}{ Chao1 } & \multirow{2}{*}{$\begin{array}{l}\text { Evenness } \\
\mathrm{J}\end{array}$} \\
\hline & $N A^{*}$ & $\mathrm{TSA}^{*}$ & WFA $^{*}$ & & & & \\
\hline $\begin{array}{l}\text { Norther Hills Zone } \\
\mathrm{NHZ}\end{array}$ & $4.87 \pm 0.07^{a b}$ & $3.26 \pm 0.05^{\mathrm{bc}}$ & $\begin{array}{l}5.19 \\
\pm 0.06^{\mathrm{b}}\end{array}$ & 2.72 & 0.95 & 16 & 0.95 \\
\hline $\begin{array}{l}\text { North Western Plains Zone } \\
\text { NWPZ }\end{array}$ & $4.74 \pm 0.02^{b}$ & $3.77 \pm 0.04^{d}$ & $\begin{array}{l}4.32 \\
\pm 0.04^{\mathrm{a}}\end{array}$ & 2.66 & 0.95 & 15 & 0.95 \\
\hline $\begin{array}{l}\text { North Eastern Plains Zone } \\
\text { NEPZ }\end{array}$ & $5.02 \pm 0.11^{\mathrm{a}}$ & $4.25 \pm 0.08^{\mathrm{a}}$ & $\begin{array}{l}4.40 \\
\pm 0.05^{\mathrm{a}}\end{array}$ & 2.41 & 0.94 & 13 & 0.94 \\
\hline $\begin{array}{l}\text { Central Zone } \\
\mathrm{CZ}\end{array}$ & $2.79 \pm 0.05^{\mathrm{e}}$ & $3.12 \pm 0.03^{c}$ & $\begin{array}{l}3.32 \\
\pm 0.05^{\mathrm{e}}\end{array}$ & 2.08 & 0.96 & 14 & 0.96 \\
\hline $\begin{array}{l}\text { Peninsular Zone } \\
\text { PZ }\end{array}$ & $3.73 \pm 0.06^{c}$ & $3.38 \pm 0.05^{b}$ & $2.99 \pm 0.04^{c}$ & 2.74 & 0.96 & 16 & 0.96 \\
\hline $\begin{array}{l}\text { Southern Hill Zone } \\
\text { SHZ }\end{array}$ & $3.14 \pm 0.04^{d}$ & $3.26 \pm 0.03^{b c}$ & $4.06 \pm 0.07^{d}$ & 2.73 & 0.96 & 16 & 0.96 \\
\hline
\end{tabular}

\subsubsection{Qualitative and quantitative analyses of phenotypic traits}

Of all the culturable WSEB isolates, about $83 \%, 72 \%, 72 \%, 46 \%, 41 \%, 57 \%, 67 \%$, and $50 \%$ tested positive for the activities of amylase, cellulase, xylanase, protease, phytase, lipase, pectinase and esterase lytic enzymes, respectively. The endophytic isolates such as NH-4, PZ-24, CZ-39, and SHZ-35 were positive for all the lytic enzymes tested. Both NWP-9 and NWP-10 were positive for all the enzymes except lipase while the isolates such as NEP-19, PZ-27 and NWPZ-60 were positive for all the enzymes except esterase (Supplementary Table 1).

The potentials for hydrolytic enzyme production varied quantitatively among the representative isolates, randomly selected eight each from the wheat cultivation zones (Table 3). The amylase activities of the selected endophytic isolates were between 8.15 and 15.17 nkatal with the minimum by the isolates from NEPZ but the maximum by the isolates from the NWPZ. Highest activities of phytase were by the WSEB of the NHZ but those from the SHZ has the lowest. The pectinase activities were lesser in the representative WSEB from the NWPZ, followed by those from the NHZ. The representative WSEB from all other zones had comparable activities. The xylanase activities were between 2.09 and 5.69 nkatal while the higher activities were in both NHZ and PZ while the lower were in the NEPZ and NWPZ. The cellulase activities were the highest in the PZ (6.64 nkatal), followed by the SHZ and NWPZ. The protease activities ranged from 2.78 to 4.79 nkatal, maximum in the PZ, followed by the NHZ. The activities of esterase were more in the culturable bacteria of the NHZ while those in the NEPZ and CZ had lesser activities. The lipase activities were the highest in the culturable bacteria from the NHZ, followed by the NWPZ while those from all other zones had comparable activities. 


\section{Plant growth promoting traits and antagonism against fungal pathogens by WSEB}

Traits such as $\mathrm{N}_{2}$ fixation, and the solubilization of phosphorous and potassium were qualitatively observed in about $46 \%$, $78 \%$ and $9 \%$ of all the endophytic bacterial isolates from the wheat seeds, respectively. Likewise, the production of IAA, siderophores, ammonia and HCN production were observed in $89 \%, 11 \%, 72 \%$ and $59 \%$ of the isolates tested, respectively. The NWP-11 isolate possessed all the traits tested qualitatively. The isolate NWP-10 was positive for all traits except the ammonia production while the isolate NEP-22 had an exception of siderophore production(Supplementary Table 2).

The production of indole acetic acid was considerably higher in the culturable bacteria from the NWPZ than those from other zones. While the WSEB from the PZ had the least potentials, those from the NHZ and SHZ, and from the NEPZ and CZ had comparable potentials for the IAA production. The acetylene reduction activity (ARA), a quantitative estimate of $\mathrm{N}_{2}$ fixation of putative endophytes were between 0.81 and $32.06 \mathrm{nmol}$ ethylene $\mathrm{h}^{-1} \mathrm{mg}^{-1}$ protein(Table 4). The isolates from the NWPZ had the highest potential for the ARA. On the contrary, the endophytic isolates from the NHZ, followed by those from the $\mathrm{CZ}$ were the poorest in their potentials for the ARA. The potentials for the phosphate solubilization were higher in the isolates from the $\mathrm{NHZ}$ and NWPZ than those from other zones. The phosphate solubilization was the least in the WSEB from the SHZ (Table 4).

The endophytes showed variable antagonistic reactions against three potent fungal pathogens tested ( $F$. graminearum, $B$. sorokiniana and $T$. indica). The endophytic isolates from each of these zones which reacted antagonistically to individual pathogens were tested for per cent inhibition. In general, the endophytic isolates from the NWPZ had higher levels of per cent inhibition against three pathogens tested(Supplementary Table 3).

Table 3

Hydrolytic enzyme activities of representative culturable endophytic bacteria isolated from different wheat cultivation zones

\begin{tabular}{|c|c|c|c|c|c|c|c|c|}
\hline $\begin{array}{l}\text { Wheat } \\
\text { cultivation } \\
\text { Zone }\end{array}$ & Amylase & Phytase & Pectinase & Xylanase & Cellulase & Protease & Esterase & Lipase \\
\hline $\begin{array}{l}\text { Norther } \\
\text { Hills Zone- } \\
\text { NHZ }\end{array}$ & $\begin{array}{l}12.61 \pm \\
0.16^{c}\end{array}$ & $\begin{array}{l}5.65 \pm \\
0.13^{d}\end{array}$ & $\begin{array}{l}2.98 \pm \\
0.04^{b}\end{array}$ & $5.69 \pm 0.09^{d}$ & $3.78 \pm 0.06^{\mathrm{a}}$ & $4.33 \pm 0.07^{c}$ & $3.10 \pm 0.04^{c}$ & $\begin{array}{l}6.55 \pm \\
0.07^{c}\end{array}$ \\
\hline $\begin{array}{l}\text { North } \\
\text { Western } \\
\text { Plains } \\
\text { Zone-- } \\
\text { NWPZ }\end{array}$ & $\begin{array}{l}15.17 \pm \\
0.16^{d}\end{array}$ & $\begin{array}{l}3.79 \pm \\
0.04^{c}\end{array}$ & $\begin{array}{l}1.01 \pm \\
0.01^{a}\end{array}$ & $2.54 \pm 0.03^{a}$ & $5.78 \pm 0.10^{c}$ & $3.30 \pm 0.05^{\mathrm{ab}}$ & $2.54 \pm 0.04^{b}$ & $4.29 \pm 0.06^{b}$ \\
\hline $\begin{array}{l}\text { North } \\
\text { Eastern } \\
\text { Plains } \\
\text { Zone-NEPZ }\end{array}$ & $\begin{array}{l}8.15 \pm \\
0.14^{\mathrm{a}}\end{array}$ & $\begin{array}{l}3.00 \pm \\
0.04^{b}\end{array}$ & $\begin{array}{l}3.25 \pm \\
0.02^{c}\end{array}$ & $2.09 \pm 0.01^{a}$ & $4.80 \pm 0.10^{b}$ & $3.55 \pm 0.03^{b}$ & $1.20 \pm 0.01^{a}$ & $2.34 \pm 0.03^{a}$ \\
\hline $\begin{array}{l}\text { Central } \\
\text { Zone-CZ }\end{array}$ & $\begin{array}{l}9.27 \pm \\
0.17^{b}\end{array}$ & $\begin{array}{l}3.72 \pm \\
0.04^{c}\end{array}$ & $\begin{array}{l}3.59 \pm \\
0.05^{c}\end{array}$ & $3.78 \pm 0.04^{b}$ & $4.69 \pm 0.08^{b}$ & $2.78 \pm 0.05^{\mathrm{a}}$ & $1.88 \pm 0.02^{\mathrm{a}}$ & $2.61 \pm 0.04^{a}$ \\
\hline $\begin{array}{l}\text { Peninsular } \\
\text { Zone-PZ }\end{array}$ & $\begin{array}{l}13.93 \pm \\
0.24^{c}\end{array}$ & $\begin{array}{l}3.93 \pm \\
0.08^{c}\end{array}$ & $\begin{array}{l}3.26 \pm \\
0.03^{c}\end{array}$ & $5.40 \pm 0.05^{d}$ & $6.64 \pm 0.09^{d}$ & $4.79 \pm 0.08^{c}$ & $2.42 \pm 0.04^{b}$ & $2.43 \pm 0.03^{a}$ \\
\hline $\begin{array}{l}\text { Southern } \\
\text { Hill Zone- } \\
\text { SHZ }\end{array}$ & $\begin{array}{l}8.45 \pm \\
0.09^{a}\end{array}$ & $\begin{array}{l}2.11 \pm \\
0.03^{a}\end{array}$ & $\begin{array}{l}3.97 \pm \\
0.06^{c}\end{array}$ & $4.86 \pm 0.04^{c}$ & $\begin{array}{l}5.86 \\
\pm 0.05^{c}\end{array}$ & $3.03 \pm 0.04^{a}$ & $4.00 \pm 0.07^{d}$ & $2.65 \pm 0.05^{\mathrm{a}}$ \\
\hline
\end{tabular}




\section{Table 4}

Plant growth promoting traits and antagonism against fungal pathogens by the representative culturable endophytic bacteria isolated from different wheat cultivation zones

\begin{tabular}{|c|c|c|c|c|c|c|}
\hline \multirow{2}{*}{$\begin{array}{l}\text { Wheat cultivation } \\
\text { Zone }\end{array}$} & \multirow[t]{2}{*}{$\mathrm{IAA}^{1}$} & \multirow[t]{2}{*}{ ARA $^{2}$} & \multirow{2}{*}{$\begin{array}{l}\text { Phosphate } \\
\text { solubilization }^{3}\end{array}$} & \multicolumn{3}{|c|}{ Antagonism against ${ }^{4}$} \\
\hline & & & & $\begin{array}{l}\text { F. } \\
\text { graminearum }\end{array}$ & $\begin{array}{l}\text { B. } \\
\text { sorokiniana }\end{array}$ & T. indica \\
\hline $\begin{array}{l}\text { Norther Hills Zone- } \\
\text { NHZ }\end{array}$ & $91.75 \pm 1.25^{\mathrm{b}}$ & $\begin{array}{l}0.81 \\
\pm 0.02^{\mathrm{a}}\end{array}$ & $415.03 \pm 5.25^{d}$ & $\begin{array}{l}39.71 \\
\pm 0.48^{\mathrm{C}}(7)\end{array}$ & $\begin{array}{l}41.47 \\
\pm 0.37^{c}(6)\end{array}$ & $35.88 \pm 0.41^{\mathrm{ac}}(6)$ \\
\hline $\begin{array}{l}\text { North Western } \\
\text { Plains Zone-NWPZ }\end{array}$ & $203.02 \pm 3.38^{d}$ & $\begin{array}{l}32.06 \\
\pm 0.31^{e}\end{array}$ & $440.25 \pm 5.63^{d}$ & $\begin{array}{l}52.35 \\
\pm 0.89^{d}(7)\end{array}$ & $\begin{array}{l}35.88 \\
\pm 0.46^{\mathrm{ac}}(5)\end{array}$ & $43.38 \pm 0.53^{\mathrm{C}}(6)$ \\
\hline $\begin{array}{l}\text { North Eastern Plains } \\
\text { Zone-NEPZ }\end{array}$ & $\begin{array}{l}152.25 \\
\pm 1.75^{\mathrm{c}}\end{array}$ & $\begin{array}{l}17.94 \\
\pm 0.18^{d}\end{array}$ & $203.25 \pm 3.38^{b}$ & $\begin{array}{l}30.81 \\
\pm 0.27^{\mathrm{ab}}(6)\end{array}$ & $\begin{array}{l}29.85 \\
\pm 0.38^{\mathrm{ab}}(6)\end{array}$ & $24.63 \pm 0.41^{\mathrm{ab}}(4)$ \\
\hline Central Zone-CZ & $158.36 \pm 1.63^{\mathrm{c}}$ & $\begin{array}{l}4.92 \\
\pm 0.13^{b}\end{array}$ & $219.25 \pm 2.01^{b c}$ & $\begin{array}{l}26.25 \pm 0.31^{b} \\
(6)\end{array}$ & $\begin{array}{l}34.78 \\
\pm 0.54^{\text {ac }}(5)\end{array}$ & $19.12 \pm 0.22^{b}(6)$ \\
\hline Peninsular Zone-PZ & $68.88 \pm 0.63^{a}$ & $\begin{array}{l}20.36 \\
\pm 0.23^{d}\end{array}$ & $226.25 \pm 1.50^{b c}$ & $\begin{array}{l}38.97 \\
\pm 0.42^{\mathrm{ac}}(6)\end{array}$ & $\begin{array}{l}29.78 \\
\pm 0.46^{\mathrm{ab}}(4)\end{array}$ & $33.75 \pm 0.41^{\mathrm{ac}}(6)$ \\
\hline $\begin{array}{l}\text { Southern Hill Zone- } \\
\text { SHZ }\end{array}$ & $111.25 \pm 1.63^{\mathrm{b}}$ & $\begin{array}{l}9.06 \\
\pm 0.06^{c}\end{array}$ & $146.75 \pm 2.50^{\mathrm{a}}$ & $\begin{array}{l}36.54 \\
\pm 0.55^{\mathrm{ac}}(4)\end{array}$ & $\begin{array}{l}24.56 \\
\pm 0.49^{b}(5)\end{array}$ & $35.15 \pm 0.32^{\mathrm{ac}}(3)$ \\
\hline \multicolumn{7}{|c|}{$\begin{array}{l}{ }^{1} \text { IAA-Indole Acetic Acid in } \mu \mathrm{g} \mathrm{ml}^{-1} ;{ }^{2} \text { ARA-Acetylene Reduction Assay- nmol ethylene } \mathrm{h}^{-1} \mathrm{mg}^{-1} \text { protein; }{ }^{3} \mathrm{P} \text { solubilisation } \mu \mathrm{g} \\
\mathrm{ml}^{-1} ;{ }^{4} \text { Antagonism in per cent }(\%) \text {. Values in parentheses are the number of isolates showed antagonism. The mean } \\
\text { values }(+ \text { S.E.) followed by the same letter(s) are not significantly different from each other }(p=0.05 \text { ANOVA followed by } \\
\text { the DMRT test). }\end{array}$} \\
\hline
\end{tabular}

The principal component analysis was performed for all the cultural phenotypes tested for the representative cultures from the six wheat cultivation zones. The analysis showed that the contributions of the first principal component (PC1) was 40.0\% while that of the second component (PC2) was $26.25 \%$, together accounting for $66.25 \%$ of variations(Fig. 2 ). The principal component (PC1) explained the maximum variation with significant negative correlations in the activities of cellulase and pectinase while those related to the activities of esterase, xylanase, protease, lipase, and phytase, the production of IAA and phosphate solubilization, and the antagonistic activities against T. indica, F. graminearum, and B. sorokiniana were found positively correlated. The phenotypic trait accounting for PC2 is xylanase showing maximum variation over cellulase.

The enzyme activities of phytase, lipase, and xylanase had positive correlation whereas amylase was negatively correlated with PC2. The majority of traits (i.e., xylanase, esterase, protease, and lipase activities and antagonism against $B$. sorokiniana) that contributed to the separation of samples had higher coefficients with the NHZ; the activities of esterase and phytase had with the PZ. The representative endophytic bacterial cultures from the NHZ and NWPZ showed maximum variance through $\mathrm{PC} 1$ axis and are considered to be highly efficient with most of the enzyme activities and antagonistic activities against three pathogens tested while those in the NEPZ had less variance, on both sides of the axis, considered in having lesser efficiencies. The analysis also showed that the $\mathrm{CZ}, \mathrm{SHZ}$, and NEPZ are closely related and the NWPZ and NHZ as the most diverged from all other cultivation zones.

\section{Colonization abilities of selected WSEB in wheat seedling roots}

The root colonization abilities of three endophytic isolates of Bacillus and one each of Pantoea and Pseudomonas, and of the non-colonizing bacterial isolate of $E$. coli as the experimental control were assayed using the TTC staining. The wheat seedlings treated with the selected endophytic isolates showed differential responses as compared to the control and the 
untreated seedlings. The visual observations after $10 \mathrm{~h}$ of treating the seedlings with bacterial cells showed the motility, gathering around root tip first and stained as pink tips of root hairs (Fig. 3). On the extension of incubation for 24 to $48 \mathrm{~h}$ led to the increased colonization of root hairs and the whole root system. The inoculated bacteria were alive, colonizing the root tips first, and then entering into root hairs. The control treatment using $E$. coli had no pigmentation, neither stained after the TTC or $\mathrm{H}_{2} \mathrm{O}_{2}$ staining. The TTC-stained roots, root hairs, and root sections clearly showed that the bacterial cells of $B$. megaterium NEP-22, P. agglomeransNWP-9, and P. putida NWP-10 adhered closely, on the surface of epidermal parenchyma, entered intracellularly and subsequently colonized the roots (Fig. 3a, 3b, 3c).

The root cells showed the intracellular presence of bacteria, stained dark brown due to the $\mathrm{H}_{2} \mathrm{O}_{2}$ staining, in tissues under the bright field microscopy (Fig.3e, 3f). Through microscopic examinations of seedlings, we observed intracellular bacteria in the roots of selected species examined. Several bacteria were observed in various locations in seedling tissues, including root hairs, root epidermal cells, and root tips. In all treated seedling roots, bacteria were seen to be located within cells, located intercellularly in seedling roots and its hairs. Bacteria were observed in root tissues but could not be visualized in shoot tissues.

\section{GFP-tagged bacterial endophytes in wheat seedlings}

The GFP plasmid (pCambia1301) vector DNA isolated from E. coli was about $11 \mathrm{~kb}$. The five predominant isolates of $T$. aestivum such as Bacillus cereus-NWPZ-5, Pantoea agglomerans-NWPZ-9, Pseudomonas putida-NWPZ-10, Bacillus megaterium-NEP-22, and Bacillus subtilisPZ-23 were selected for the preparation of competent cells, and tagged with GFP plasmid vector through transformation process at different temperatures and timings. The bacterial colonies from the Kan $\mathrm{n}_{50}$ NA plate were prepared for the confocal microscopy and the tagged cells were observed as in Fig.4. The colonization patterns of the tagged isolates differed in the tissues. Out of the isolates tested, two of them belonging to the most prevalent bacterial groups (Pantoeaspp. and Pseudomonas spp.) among all the wheat seeds were easier to transform than the other prevalent group of Bacillus spp. When the GFP-tagged endophytes were treated with wheat seeds, more light-green autofluorescence was observed in leaves, compared to root and stem of seedlings. In general, the GFP-tagged cells were more on $7 \mathrm{~d}$ after inoculation, than on 5 or $15 \mathrm{~d}$ after inoculation. After $15 \mathrm{~d}$ of inoculation, the endophytic colonization was more in inter- and intra-cellular spaces in roots, leaves, and the xylem vessels of the stem(Fig.4a, 4b, 4c, 4d, 4e). The matrix such as the soft agar medium did not affect the colonization pattern while the rapid spread in the vascular system suggesting the systemic colonization. The seedlings under the hydroponic condition led to greater colonization of GFP-tagged cells in stem, with lesser in root apices, root hairs and leaves. But the GFP-tagged bacterial cells colonized the zone of lateral root emergence, root tips and in the intercellular spaces of root epidermis.

\section{Discussion}

The culturable bacterial endophytes in seeds of popular wheat genotypes that were characterised from six agro-ecological zones showed their beneficial roles, and their potential for colonization and growth promotion in germinating plants. The soils of these agro-ecological zones differ in their physico-chemical properties(Table 1) and there are many variations among climatic variables that have contributed to the adaptative traits and the popularity of certain wheat genotypes. In the wheat genotypes (about 21) tested, the composition of culturable bacteria at the levels of genus and species level was inconsistent in seeds. Nevertheless, there are common culturable bacterial endophytes in wheat seeds suggesting them as the significant constituents of seeds. In an earlier study by Robinson et al. (2016), the seed borne microbial communities in roots and shoots of the axenically grown seedlings were characterized by isolation and cultivation. Only eight bacterial taxa could be defined at the genus level in their study. However, the optimized isolation protocols followed in the present study helped to identify higher diversity of seed bacterial endophytes from the popular wheat genotypes cultivated in six different agro-ecological zones. These new isolates thereby suggest their possible roles in seed development and the ensuing plant growth, and provide an extended microbial resource for further research. What are interesting to know are how abundant these bacterial members are, what their functional characteristics are, and how they are protected in seeds. 
Many bacterial seed endophytes isolated from wheat seed genotypes could form endospores. Earlier, Compantet al. (2011) observed that the seed endophytes had the ability to form endospores, thus providing protection from changing conditions inside seeds. These endophytes have other traits such as cell motility and phytase activity to migrate freely inside the plant and enter the seeds before they harden. Nevertheless, there are relatively few studies examining the diversity of seed-borne endophytes.

In the present study, both the number of endophytic bacterial phyla and total number of culturable bacteria varied inside seeds of different genotypes. The members of the phyla Firmicutes, Actinobacteria, Proteobacteria were predominant in the wheat genotypes tested. The most abundant member of Firmicutes was the Bacillus species (about 40 identified) and other numbers of identified species (three each) belonged to Actinobacteria and Proteobacteria. Nevertheless, there were significant differences among the bacterial community at the level of OTU in seeds. In earlier report on seeds of rice variety (CT6919), the microbiological, physiological, and molecular characterization of about 39 fast-growing seed-borne bacterial flora revealed the diversity of seed-borne mesophiles with the potentials for plant probiotic activities such as diazotrophy and antagonism of fungal pathogens. The seed-borne bacteria were found to protected the rice seedlings against the infection of Curvularia sp. (Ruiza et al., 2011). The functional roles of seed endophytes belonging to Firmicutes, Actinobacteria and Proteobacteria still remain quite elusive. Xu et al. (2014) reported that bacteria belonging to several genera showed plant growth promotion (PGP) and biocontrol activities, suggesting the fascinating hypothesis of a bacterial-plant co-evolution and functional selection.

The wheat seed endophytic bacteria can improve germination, plant growth, and the suppression of host plant pathogens. These endophytic bacteria can directly facilitate the germination process and the proliferation of their plant host through the production of the stimulatory phytohormones and hydrolytic enzymes. IAA, the best characterized auxin among the phytohormones, is essential for the growth and development of plants. The wheat seed endophytic bacteria isolated from different agro-ecological zones in the present study possess the functional characteristic of IAA production. The results of the present study corroborated with the report of Khalaf and Raizada (2016) who isolated cucurbit seed-associated endophytes with plant growth promoting traits such as phytohormone biosynthesis and nutrient acquisition. In addition to the phytohormone production, plant growth promotion is mediated by a variety of mechanisms including the solubilization of phosphorus, potassium and zinc; production of ammonia, siderophores and HCN (Tilak et al., 2005). There are considerable populations of P- or K-solubilizing bacteria observed in seeds of rice, wheat and other plant species. The P-solubilizing bacteria (PSB) can solubilize inorganic phosphate compounds, such as tricalcium phosphate (Vyas et al., 2009). In the present study the P-solubilization activity was exhibited by many genera such as Alcaligenes, Arthrobacter, Achromobacter, Bacillus, Delftia, Methylobacterium, Pseudomonas, Rhodobacter, Staphylococcus, and Salmonella. Most seed endophytes isolated from different genotypes possessed the $\mathrm{P}$ solubilization abilities while relatively a few isolates could fix nitrogen in the present study. Similarly, Johnston-Monje and Raizada (2011) reported that most of the bacterial isolates from seeds of different maize genotypes could solubilize phosphorus, secrete acetoin and fix nitrogen. In addition, the ACC deaminase activity and antibiosis were found to be moderately conserved among these seed endophytes from different maize genotypes.

Van den Berg (2017) reported that up to one third of in vitro tested endophytes exhibiting activity against plant pathogens. In the present study, seeds of different wheat genotypes had endophytes with antagonistic activities against Fusarium, Bipolaris and Tilletia, three of the most important soil-borne pathogens. Our findings corroborated with the report of Van den Berg (2017) that a large number of seed-associated endophytes $(54 \%, 25 / 46)$ could antagonize the phytopathogens tested. In another report, Herrera et al. (2016) isolated endophytes from wheat seeds such as Paenibacillus sp., Pantoea sp., and Bacillus sp., which significantly enhanced plant growth and resistance against $F$. graminearum. Numerous cucurbit seedassociated bacterial endophytes possess the extracellular lytic enzyme activities, including cellulase, pectinase and protease (Khalaf and Raizada, 2016). The presence of endophytes with extracellular lytic enzymes is relevant as several biocontrol agents exert their antagonistic activity through secretion of lytic enzymes, protecting the host plants either directly or indirectly. The direct mechanisms involve breaking down of essential complex polymers within the pathogen such as chitin, 
protein, cellulose and DNA (Pliego et al., 2011). Even the lysis products (e.g., chitin fragments) can be indirectly employed in plant protection by eliciting host defence responses (Duran-Flores and Heil, 2016).

On inoculation of wheat seedlings with endophytic bacterial suspensions, the root colonization was observed with $\mathrm{H}_{2} \mathrm{O}_{2}$ staining, more in the inoculated seedling roots than the uninoculated roots. The possibility of some endophytic bacteria that remained in the surface sterilized control seedlings existed; bacteria in the control roots were however present in low numbers. Paungfoo-Lonhienneet al. (2010) showed that the bacterial entry into cells was accompanied by upregulation of plant cell wall related enzymes such as cellulases, pectinases, xyloglucan endotransglycosidases, cellulose synthases, and expansins. The involvement of host enzymes suggests that plant cells engage in phagocytosis to acquire bacteria. In addition to the host involvement, bacteria may also produce the cell wall loosening- and degrading enzymes to colonize the interior of plant cells. Many symbiotic bacteria enter plant cells using their own cell wall degrading enzymes. The capacity of Klebsiellaoxytoca to endophytically colonize wheat plants correlated with its ability to produce pectinases (Kovtunovychet al. 1999). The vital staining using 2,3,5-triphenyl tetrazolium chloride (TTC) helps to detect the live endophytic bacteria (Bacon et al., 2002; Thomas, 2011). In the present study, the vital staining showed the intra-tissue presence of some live bacteria that are motile and of those non-motile members.

The seed endophytic bacteria isolated from different wheat seed genotypes in the present study have multifunctional traits such as hydrolytic enzyme production, plant growth promotion by the synthesis of phytohormones and nutrient acquisition, biocontrol activity and enhanced survival fitness at the high salt concentration, drought stress and high temperature. Similarly, Bodhankaret al. (2017) isolated many maize seed endophytic bacteria (MSEB) from 30 genotypes and found that the dominant genus was Bacillus of Phylum Firmicutes with a few isolates belonging to the genus Staphylococcus and an isolate belonging to Corynebacterium species of Phylum Actinobacteria. The isolate of Corynebacterium species exhibited multifunctional traits related to the plant growth promotion and activities such as antagonism against phytopathogenic fungi, production of ammonia and secretion of lytic enzymes. In addition, many MSEB exhibited tolerance to salinity (10\%), osmotic stress (40\% PEG6000), and temperature $\left(60^{\circ} \mathrm{C}\right)$ (Bodhankaret al. 2017).

The colonization of wheat seed endophytes was confirmed through the use of both the $\mathrm{H}_{2} \mathrm{O}_{2}$ and the 2,3,5-triphenyl tetrazolium chloride (TTC) staining methods in the present study. In general, endophytes colonize the host plants, predominantly in roots and are often present in low abundance, relative to the rhizoplane colonizers (Bulgarelliet al. 2012). Compared to the root colonizers, the culturable endophytes are less in numbers in seeds. The vital staining using TTC for detection of live endophytic bacteria showed the presence of both the motile and non-motile members, supporting with the earlier report of Thomas (2011) in many other plant species. The colonization of plant tissues is advantageous to bacteria as there is less competition for plant nutrients, relative to those bacteria which colonize the plant (exterior) surfaces (Rosenblueth and Martínez-Romero, 2006). Moreover, endophytic bacteria within the plant tissues get better protection from abiotic stresses compared with surface colonizers (Hallmannet al., 1997). The colonization routes of seed endophytic bacteria include their entry through roots, either through passive penetration (via root tip, side root emergence or pathogen entry sites) or active penetration (using cell wall degrading enzymes such as cellulase and pectinase) (Ebeltagyet al., 2000; James et al., 2002).

\section{Methods}

\section{Ecology, Wheat Genotypes, Seed Sourcing and Processing}

Twenty wheat genotypes growing in six agro-ecological zones were selected for sourcing seeds; four different locations in each zone that have characteristic features related to the total area and productivity, number of varieties released, and major constraints of wheat cultivation were selected (Table 1). The composite seed samples of each genotype were pooled and 15 seeds were randomly collected for isolating endophytic bacteria. The seeds of each genotype were surface-sterilized separately using sodium hypochlorite (4\%) for 3 min with shaking, followed by washings with sterile distilled water. Then, these seeds were immersed in ethanol (75\%) for $4 \mathrm{~min}$, followed by repeated washings with sterile distilled water for complete 
removal of traces of sterilant. An aliquot of the final rinse $(100 \mu \mathrm{l})$ was tested for the surface sterilization efficiency by plating on the trypticase soy agar (TSA) and incubating at $28 \pm 1{ }^{\circ} \mathrm{C}$ for three days. The seeds free of surface bacteria were immersed in sterile water for $1 \mathrm{~h}$ to soften the layers for the enumeration and isolation of endophytes.

\section{Endophytic bacterial extraction from seeds}

The culturable bacterial endophytes were enumerated and isolated using trypticase soya agar (TSA) and nutrient agar (NA) media, and the newly developed wheat flour-based agar (WFA) medium(SaiPrasad, et al. 2020) that contained wheat flour $(1 \%)$, yeast extract $(0.1 \%)$, sodium chloride $(0.05 \%)$ and agar $(1.8 \%)$. Seed coats of swollen surface-sterilized seeds were removed gently, using a sterilized scalpel, to get endosperm under aseptic conditions. For isolation of endophytic bacteria, endosperms were pressed with the scalpel mildly and placed on agar plates of different growth media; each plate with five endosperms in triplicates for each genotype tested, were incubated at $28 \pm 1^{\circ} \mathrm{C}$ for $4-5$ days. The bacterial colonies in and around endosperms were further picked up, streaked, and purified for isolation on the respective medium plates. For enumerating endophytic bacteria, the surface-sterilized seed endosperm of each genotype (one gram each) was crushed in a sterile mortar pestle. The standard serial dilution plating technique was followed for counting the CFUs. The pure bacterial colonies as the wheat seed endophytic bacteria (WSEB) were maintained on the slants of NA as working cultures at $4{ }^{\circ} \mathrm{C}$, and in the glycerol stocks $(30 \%)$ at $-20^{\circ} \mathrm{C}$ for further use as described earlier (Robinson et al., 2016).

\section{Phenotyping and Phylotyping of Wheat Seed Endophytic Bacteria (WSEB)}

The phenotyping of isolates of WSEB in terms of color, size, and other colony characteristics such as form, margin, elevation and pigmentation on agar medium, and differential staining for Gram reactions and spore formation was done following Bergey's Manual of Determinative Bacteriology (Holt et al., 1994). All the isolates of WSEB were screened for their growth potential at different temperatures $\left(4-40^{\circ} \mathrm{C}\right), \mathrm{pH}(3$ to 10$)$, and salt (5-15\%), after the overnight grown cultures $\left(10^{8}\right.$ cells $\left.\mathrm{ml}^{-1}\right)$ were spot-inoculatedon different plates. The nutrient agar amended with polyethylene glycol (PEG 6000 at 10 and $15 \%$ ) were used for spot-inoculation and incubated at $28{ }^{\circ} \mathrm{C}$ for $48 \mathrm{~h}$ for examining tolerance to the drought-like (deficient water availability) stress. Testing of phenotypes of these isolates included the hydrolase production, plant growth-promoting traits and biocontrol activities. All tests were performed in triplicate, using different standard protocols.

\section{Qualitative evaluation for hydrolases}

The WSEB isolates were screened qualitatively for hydrolytic enzymes such as amylase, cellulase, xylanase, protease, pectinase, phytase, esterase and lipase by using suitable substrates. Amylase activity was tested using starch agar plates, and cellulase activity was determined using carboxy methyl cellulose according to the methods of Sahuet al. (2005) and Emmyrafedziawati and Stella (2015), respectively. The selective xylan-agar plates containing 1\% (w/v) birchwoodxylan were used for xylanase activity (Smibert and Krieg, 1994). Activities of pectinase on media containing pectin (1\%) as the sole carbon source were screened (Hankinet al., 1971).

On the plates containing the medium (glucose- $1.5 \%, \mathrm{NH}_{4} \mathrm{NO}_{3}-0.5 \%$, calcium phytate- $0.5 \%, \mathrm{MgSO}_{4} \cdot 7 \mathrm{H}_{2} \mathrm{O}-0.05 \%, \mathrm{KCl}-0.05 \%$, $\mathrm{FeSO}_{4} \cdot 7 \mathrm{H}_{2} \mathrm{O}-0.001 \%, \mathrm{MnSO}_{4} \cdot 4 \mathrm{H}_{2} \mathrm{O}-0.001 \%$, and agar- $2.0 \%$ ), phytate utilization was tested; lipase activity on the medium composed ofpeptone (1\%), $\mathrm{NaCl}(0.5 \%), \mathrm{CaCl}_{2}(0.01 \%)$ Tween $20(1 \% \mathrm{v} / \mathrm{v})$, and agar-agar (1.5\%) with pH 7.4, and esterase activity by replacing Tween 20 with Tween 80 in the above-mentioned medium were screened (Plou et al., 1998).

\section{Quantitative estimation of hydrolase activities}


The active cultures of bacterial isolates (eight each) were randomly selected from the representative zone and inoculated into broth containing soluble starch (1\%), peptone (0.5\%), $\left(\mathrm{NH}_{4}\right)_{2} \mathrm{SO}_{4}(0.2 \%), \mathrm{KH}_{2} \mathrm{PO}_{4}(1 \%), \mathrm{K}_{2} \mathrm{HPO}_{4}(0.2 \%), \mathrm{MgCl}_{2}(0.001 \%)$ at $\mathrm{pH}$ 7 and incubated on a shaker at $150 \mathrm{rpm}$ for 3 days at $30^{\circ} \mathrm{C}$. After incubation, the culture was centrifuged at $10000 \mathrm{rpm}$ for 15 min at $4{ }^{\circ} \mathrm{C}$; the cell-free supernatant was prepared to serve as the enzyme source. The amylase activity was assayed by the method of Bernfeld (1955) with some modifications (Miller, 1959). The cellulase activities of cultures were estimated as described earlier (Lisdiyantiet al., 2012); the activities of xylanase by the method of Saha (2002). The activities of protease and phytase were assayed by the methods of Tsuchida (1986) and Fiske (1925), respectively. Lipase activity was determined using p-nitrophenol palmitate (pNPP) as a substrate described earlier (Karadzic, 2006). Citrus pectin (0.5\% (w/v) in $0.1 \mathrm{M}$ of $\mathrm{pH} 7.5$ phosphate buffer was used for estimating pectinase activity (Rehman 2012). Esterase activity was determined by using hydrolysis of p-nitrophenyl butyrate (pNPB) as a substrate as described by Karadzic (2006).

\section{Phenotyping of WSEB for plant growth promotion traits}

The qualitative screening of their plant growth promoting (PGP) attributes viz. estimation of solubilization of nutrients (phosphorus, potassium) and production of phytohormone indole-3-acetic acid, siderophores, HCN and ammonia was determined by the standard methods (Pikovskaya, 1948; Hu et al., 2006; Schwyn and Neilands, 1987; Bricet al. 1991; Bakker and Schippers 1987; Cappucino and Sherman 1992, respectively). The nitrogen-fixing potential of the WSEB was tested using the acetylene reduction assay (ARA) (Hardy et al., 1968). The bacterial isolates were assayed under aerobic and microaerophilic conditions, after inoculation in solid and semisolid nitrogen free medium into $30 \mathrm{~mL}$ vials and incubation for 7 days at $30^{\circ} \mathrm{C}$. Then the vials were sealed with rubber septa, and the gas phase of each vial was replaced with a gas mixture of nitrogen, air, and acetylene (90:10:10, v/v) and cultures were re-incubated at $30^{\circ} \mathrm{C}$ for $24 \mathrm{~h}$. The amount of ethylene produced by acetylene reduction was measured in a gas chromatograph (F11, PerkinElmer, USA), and expressed on the basis of protein, determined by the standard Bradford (1976) method. The P-solubilisation was quantitatively estimated by the method of Mehta and Nautiyal (2001). Indole acetic acid production was estimated according to Patten and Glick (2002). All assays were done in triplicates using the isolates from each representative zone.

\section{Antagonistic activities of WSEB against fungal pathogens}

Three fungal pathogenic strains (Fusarium graminearum (ITCC 3437), Bipolarissorokinianaand Tilletiaindica)were collected from the Division of Plant Pathology, Indian Agricultural Research Institute, New Delhi, India. The actively growing fungal strains ( $1 \mathrm{~cm}^{2}$ plug) were inoculated on one side of the PDA plates, the other side of plates were streaked with bacterial endophytes at equidistant points of the plate, and incubated at $25^{\circ} \mathrm{C}$ for 7 days. All the WSEB were assayed for antifungal activities using dual cultures on the PDA plates according to Sijam and Dikin (2005). The culture assays were repeated three times per isolates and for each fungus.

\section{Phylotyping using 16S rRNA genes}

All the selected WSEB isolates (46) were characterized phylogenetically, using the 16S rRNA gene sequencing. The genomic DNA of these isolates was extracted using Zymo Research (ZR) Bacterial DNA MiniPrep ${ }^{\text {TM }}$ extraction kit according to the manufacturer protocol (The Epigenetic Company). The quality \& quantity of the extracted DNA was examined by running on agarose gel electrophoresis. The 16SrRNA gene of genomic DNA was amplified with forward pA(27F) and reverse $\mathrm{pH}$ (1492R) primers using PCR thermocycler (peqSTAR 96, VWR International GmbH, Vienna). The reaction mixtures contained the master mix $(10 \mu \mathrm{l})$ containing $10 \times$ Taq buffer, dNTPs $(10 \mathrm{mM}), \mathrm{MgCl}_{2}(25 \mathrm{mM})$ Taq DNA polymerase $(1 \mathrm{U})$, forward and reverse primers $(1.5 \mu \mathrm{l})$, and genomic DNA $(2 \mu \mathrm{l})$ and the PCR grade water $(5 \mu \mathrm{l})$. The thermal cycler was programmed for 35 cycles. The PCR products were sequenced the Sanger dideoxy method (AgriGenome, TDI Centre, New Delhi); the sequence data were compared with known sequences in GenBank using BLAST, NCBI. Species identification was based on the

Page $12 / 21$ 
percentage similarity with known species sequences in the data base; the partial 16SrRNA gene sequences were submitted to NCBI GenBank under the assigned accession numbers (MT184815- MT184857)

\section{Colonization of WSEB and their visualization in the emerging plants}

The surface-sterilized seeds were inoculated by soaking in the $24 \mathrm{~h}$-old bacterial suspensions for $60 \mathrm{~min}$. These treated seeds were placed on petri-plates with soft agar (0.8\%), and kept for incubation in the light: dark (12:12) condition at $20^{\circ} \mathrm{C}$ for $5-7$ days (seedling stage). For each culture, three plates with five seeds each were maintained. The controls included seeds without bacterial culture treatment. The bright-field microscopy of seedling roots was done for visualizing the live isolates of endophytes using two stains, TTC and $\mathrm{H}_{2} \mathrm{O}_{2}$. Each plate with seedlings was flooded with TTC $\left(1.5 \mathrm{~g} \mathrm{~L}^{-1}\right)$, malic acid (625 mg $\mathrm{L}^{-1}$ ) solution in $0.05 \mathrm{M}$ potassium phosphate buffer ( $\mathrm{pH}$ 7.0) for $10 \mathrm{~h}$, as described earlier (Bacon et al., 2002; Thomas and Reddy, 2013). After incubation, roots, and leaves were excised from seedlings under aseptic conditions, rinsed with sterile water to remove any external organisms, and examined by the vital bacterial staining technique with cells turned pink or red. Tissue sections were mounted in sterile water, and the images were captured using bright-field microscope (Dewinter, India). In another set of seedlings, the bacterial internalization in roots of seedlings (1- to 3-week-old) was stained for $10 \mathrm{~h}$ by flooding soft agar plates with potassium phosphate buffer ( $5 \mathrm{ml}, \mathrm{pH} 6.9 \& 100 \mathrm{mM}), 3$, 30-diaminobenzidine tetrachloride (DAB) $(2.5 \mathrm{mM})$ and 5 purpurogallin unit's $\mathrm{mL}^{-1}$ of horseradish peroxidase. The roots and shoots of seedlings were then excised, placed them on a slide containing aniline blue/lactophenol stain (aniline blue dye $0.05 \mathrm{~g}$, phenol crystals $20 \mathrm{~g}$, glycerol $40 \mathrm{~mL}$, lactic acid $20 \mathrm{~mL}, \mathrm{H}_{2} \mathrm{O} 20 \mathrm{~mL}$ ) and were examined using the bright field microscopy (White et al., 2014).

\section{Tagging and tracking of seed endophytes using GFP expression vector}

The green fluorescent protein ( $g f p$ ) plasmid DNA vector was isolated from E. coli using the alkali method (Bimboim and Doly 1979). The isolated plasmid DNA was checked for quality and its size on agarose gel (1.2\%). The competent cells of selected bacterial endophytes (both Gram-positive and Gram-negative isolates) were prepared using $\mathrm{CaCl}_{2}$, and $\mathrm{MgCl}_{2}(0.1 \mathrm{M})$; the isolated GFP plasmid DNA $(10 \mu \mathrm{L})$ was mixed gently with competent cells $(200 \mu \mathrm{l})$. Transformation events were standardised for the Gram-positive and Gram-negative isolates and the transformation efficiencies were calculated. The transferred colonies were re-streaked on NA-Kan ${ }_{50}$ plates and the colonies were observed under fluorescence (Dewinter, India) and confocal laser scanning microscope (Leica DMIRE2 \& DM IRB system) using an excitation laser of $488 \mathrm{~nm}$ (Argon laser) and collecting the emission band of 500-550 nm for fluorescence. Additionally, the colony PCR was performed to determine the insert of the plasmid vector into the transformed cells using mGFP primers forward (TCAGTGGAGAGGGTGAAGGT) and reverse (GTGGTGGTGGCTAGCTTTGT) using PCR thermocycler (peq STAR 96) (Edwards et al., 1989). The phylotyping of GFP tagged endophytes was performed using the 16S rRNA genes, the sequences were determined by the Sanger Dideoxy method (Agrigenome, India), and identified by BLAST.

The GFP tagged endophytes were bioassayed for their potentials to colonize wheat plants, in soft agar plates and in hydroponic conditions under aseptic condition using the Hoagland solution, as described by Elliott and Lynch (1984). Proper guidelines have been followed for laying out the experiment and destructive sampling as per IARI Phytotron guidelines. The GFP tagged bacterial endophytes $\left(10^{6}\right.$ cells $\left.\mathrm{mL}^{-1}\right)$ were treated with the surface-sterilized seeds for $1 \mathrm{~h}$ under the aseptic condition. The observations on seed germination were made on 24,48 and $72 \mathrm{~h}$ in the plate assay. For the soft agar plateand the hydroponics-based assays, after 12 days, the fresh roots that grew along the inner wall of plate and leaves were excised from seedlings under aseptic conditions. The tissue sections of roots and leaves were prepared by cutting into pieces around $1 \mathrm{~cm}$ in length with a sterile razor blade, and these sections were kept on the oil free glass slides with addition of sterile double distilled water droplets to avoid dryness. The sample glass slides were later observed by the confocal laser scanning microscopy. The transmission light was collected to visualize root structure particularly GFP fluorescence of cells was viewed and images were acquired and reconstructed by Leica Confocal Software (LCS 2.6) and picture was saved using different objective lens (i.e., 10x, 40x, and 100x).

Page $13 / 21$ 


\section{Statistical analysis}

The 16S rRNA gene sequences of the isolates showing >P 99\% sequence similarity were grouped into the same OTU (phylotype). The Shannon index (H), Evenness (J), Simpson's index (D) and Chao-1 were calculated as described earlier (Schloss et al., 2009). Principal coordinate analysis (PCA) was performed for different plant growth promoting attributes of bacterial isolates using the R software (https://www.r-project.org/). Other statistical calculations were done using MS-Excel. Sequence alignment and comparison was performed, using the program CLUSTAL-W software. One sequence from each group was selected as a representative operational taxonomic unit (OTU). The phylogenetic tree was constructed on the aligned datasets using the neighbor-joining method implemented in the program MEGA 6 software (Tamura et al., 2007).

\section{Conclusion}

The culturable endophytic bacteria from the seeds of different genotypes provide new insights into their composition and the potential for colonization. The environmental conditions have a significant effect on their diversity. In addition, our study showed that the genotypes play a profound role in their diversity, with variations in the hydrolytic enzyme production, plant growth promotion and priority effects on seedling colonization. The diversity analysis showed that highest values of diversity indices such as Shannon diversity $(\mathrm{H})$, Chao1, Simpson's reciprocal index and Species evenness $(\mathrm{J})$ were generally in the PZ, followed by the NHZ. These endophytes (WSEB) showed variations in the functional traits such as plant growth promotion related to $\mathrm{N}_{2}$ fixation, and phosphorous and potassium solubilization. Of eight hydrolytic enzymes tested qualitatively, the maximum number of isolates were positive for amylase (83\%) followed by cellulase (72\%), and xylanase (72\%); the least number of isolates were positive in phytase (41\%). Higher potentials for hydrolytic enzyme production suggest the multifarious mechanisms mediated by these seed endophytic bacteria for colonization and antagonism against plant pathogens.

\section{Declarations}

\section{Acknowledgement}

Authors thank Dr RK Sharma, Principal Scientist, Division of Genetics for sourcing wheat seeds from different ecologies. Support from Divisions of Biochemistry and Plant Pathology is acknowledged for GUS assay and confocal microscopy. Authors thank Phytotron Services at IARI for conducting plant assays under hydroponic conditions. Financial support to JS from World Bank-ICAR funded National Agricultural Higher Education Project (NAHEP), Centre for Advanced Agricultural Science and Technology (CAAST) on Genomics- Assisted Crop Improvement and Management, ICAR-IARI, New Delhi is gratefully acknowledged.

\section{Data availability}

The data sets analysed during the current study are available in the NCBI databases repository (www.ncbi.nlm.nih.gov/genbank); Accession numbers MT184815- MT184857.

All data generated during this study are included in this published article and its Supplementary Information files.

\section{References}

1. Bacon, C. W., Glenn, A. E. \& Hinton, D. M. Isolation In Planta Detection and Culture of Endophytic and Fungi (Manual of Environmental, 2002)

2. Bakker, A. W. \& Schippers, B. Microbial cyanide production in the rhizosphere in relation to potato yield reduction and Pseudomonas SPP-mediated plant growth-stimulation. Soil Biol Biochem, 19 (4), 451-457 (1987). 
3. Berg, G., Grube, M., Schloter, M. \& Smalla, K. Unraveling the plant microbiome: looking back and future perspectives. Frontiers in Microbiology, 5, 148 (2015).

4. Bernfeld, P. Methods in Enzymology; Colowick, SP, Kaplan, NO, Eds. Academic Press New York, 1: 149(1955).

5. Bimboim, H. C. \& Doly, J. A rapid alkaline extraction procedure for screening recombinant plasmid DNA. Nucleic acids research, 7 (6), 1513-1523 (1979).

6. Bodhankar, S. et al. Maize seed endophytic bacteria: dominance of antagonistic, lytic enzyme-producing Bacillus spp. 3 Biotech, 7, 232 (2017).

7. Bradford, M. M. A rapid and sensitive method for the quantitation of microgram quantities of protein utilizing the principle of protein-dye binding. Analytical biochemistry, 72 (1-2), 248-254 (1976).

8. Bric, J. M., Bostock, R. M. \& Silverstone, S. E. Rapid in situ assay for indoleacetic acid production by bacteria immobilized on a nitrocellulose membrane. Applied and environmental Microbiology, 57 (2), 535-538 (1991).

9. Bulgarelli, D. et al. Revealing structure and assembly cues for Arabidopsis root-inhabiting bacterial microbiota. Nature, 488 (7409), 91-95 (2012).

10. Cappucino, J. C. \& Sherman, N. Nitrogen Cycle. In: Microbiology: A Laboratory Manual. 4th ed.Benjamin/Cumming Pub. Co., New York,311-312(1992).

11. Compant, S., Mitter, B., Colli-Mull, J. G., Gangl, H. \& Sessitsch, A. Endophytes of grapevine flowers, berries, and seeds: identification of cultivable bacteria, comparison with other plant parts, and visualization of niches of colonization. Microb. Ecol, 62 (1), 188-197 (2011).

12. Duran-Flores, D. \& Heil, M. Sources of specificity in plant damagedself-recognition. Curr. Opin. Plant Biol, 32, 77-87 (2016).

13. Edwards, U., Rogall, T., Blöcker, H., Emde, M. \& Böttger, E. C. Isolation and direct complete nucleotide determination of entire genes. Characterization of a gene coding for 16S ribosomal RNA. Nucleic Acids Res, 17 (19), 7843-7853 (1989).

14. Elbeltagy, A. et al. Isolation and characterization of endophytic bacteria from wild and traditionally cultivated rice varieties. Soil science and plant nutrition, 46 (3), 617-629 (2000).

15. Elliott, L. F. \& Lynch, J. M. Pseudomonads as a factor in the growth of winter wheat (Triticum aestivum L.). Soil Biol. Biochem, 16 (1), 69-71 (1984).

16. Emmyrafedziawati, A. K. R. \& Stella, M. Hydrolysis of carboxymethyl cellulose (CMC) by Bacillus isolated from compost. J. Trop. Agric. and Fd. Sc, 43 (2), 129-135 (2015).

17. Fiske, C. H. \& Subbarow, Y. The colorimetric determination of phosphorus. J. biol. Chem, 66 (2), 375-400 (1925).

18. Gagne-Bourgue, F. et al. Isolation and characterization of indigenous endophytic bacteria associated with leaves of switchgrass (Panicumvirgatum L.) cultivars. J. Appl. Microbiol, 114, 836-853 (2013).

19. Hallmann, J., Quadt-Hallmann, A., Mahaffee, W. F. \& Kloepper, J. W. Bacterial endophytes in agricultural crops. Canadian journal of microbiology, 43 (10), 895-914 (1997).

20. Hankin, L., Zucker, M. \& Sands, D. C. Improved solid medium for the detection and enumeration of pectolytic bacteria. Appl. Microbiol, 22 (2), 205-209 (1971).

21. Hardy, R. W., Holsten, R. D., Jackson, E. K. \& Burns, R. C. The acetylene-ethylene assay for N2 fixation: laboratory and field evaluation. Plant physiology, 43 (8), 1185-1207 (1968).

22. Herrera, S. D., Grossi, C., Zawoznik, M. \& \&Groppa, M. D. Wheat seeds harbour bacterial endophytes with potential as plant growth promoters and biocontrol agents of Fusarium graminearum. Microbiol. Res, 37 (43), 186-187 (2016).

23. Holt, J. G., Krieg, N. R. \& Sneath, P. H. Bergey's manual of Determinative Bacteriology(1994).

24. Hu, X., Chen, J. \& Guo, J. Two phosphate-and potassium-solubilizing bacteria isolated from Tianmu Mountain, Zhejiang, China. World journal of Microbiology and Biotechnology, 22 (9), 983-990 (2006).

25. James, E. K. et al. Infection and colonization of rice seedlings by the plant growth-promoting bacterium Herbaspirillum seropedicae Z67. Mol. Plant Microbe Interact, 15 (9), 894-906 (2002).

Page $15 / 21$ 
26. Johnston-Monje, D. \& \&Raizada, M. N. Conservation and Diversity of Seed Associated Endophytes in Zea across Boundaries of Evolution, Ethnography and Ecology. PLOS ONE, 6 (6), e20396 (2011).

27. Johnston-Monje, D., Lundberg, D. S., Lazarovits, G. \& Reis, V. M. \&Raizada, M. N. Bacterial populations in juvenile maize rhizospheres originate from both seed and soil. Plant and Soil, 405 (1), 337-355 (2016).

28. Karadzic, I., Masui, A., Zivkovic, L. I. \& Fujiwara, N. Purification and characterization of an alkaline lipase from Pseudomonas aeruginosa isolated from putrid mineral cutting oil as component of metalworking fluid. Journal of Bioscience and Bioengineering, 102 (2), 82-89 (2006).

29. Khalaf, E. M. \& Raizada, M. N. Taxonomic and functional diversity of cultured seed associated microbes of the cucurbit family. BMC Microbiol, 16, 131 (2016).

30. Kovtunovych, G. et al. Correlation between pectate lyase activity and ability of diazotrophic Klebsiellaoxytoca VN 13 to penetrate into plant tissues. Plant and Soil, 215 (1), 1-6 (1999).

31. Lisdiyanti, P., Suyanto, E., Gusmawati, N. F. \& Rahayu, W. Isolation and characterization of cellulase produced by cellulolytic bacteria from peat soil of OganKomeringllir, South Sumatera. International journal of environment and bioenergy, 3 (3), 145-153 (2012).

32. Malfanova, N., Lugtenberg, B. \& Berg, G. Bacterial endophytes: who and where, and what are they doing there.Molecular microbial ecology of the rhizosphere,15-37(2013).

33. Mano, H. et al. Culturable surface and endophytic bacterial flora of the maturing seeds of rice plants (Oryzasativa) cultivated in a paddy field. Microbes Environ, 21, 86-100 (2006).

34. Mehta, S. \& \&Nautiyal, C. S. An efficient method for qualitative screening of phosphate-solubilizing bacteria. Current microbiology, 43 (1), 51-56 (2001).

35. Miller, G. L. Use of dinitrosalicylic acid reagent for determination of reducing sugar. Analytical chemistry, 31 (3), 426-428 (1959).

36. Mishra, P. K. et al. Alleviation of cold stress in inoculated wheat (Triticumaestivum L.) seedlings with psychrotolerant Pseudomonads from NW Himalayas. Archives of microbiology, 193 (7), 497-513 (2011).

37. Patten, C. L. \& Glick, B. R. Role of Pseudomonas putida indoleacetic acid in development of the host plant root system. Applied and environmental microbiology, 68 (8), 3795-3801 (2002).

38. Paungfoo-Lonhienne, C. et al. Turning the table: plants consume microbes as a source of nutrients. PLOS one, 5 (7), e11915 (2010).

39. Pikovskaya, R. I. Mobilization of phosphorus in soil in connection with vital activity of some microbial species., 17, 362370 (1948).

40. Pliego, C., Ramos, C., de Vicente, A. \& Cazorla, F. M. Screening for candidate bacterial biocontrol agents against soilborne fungal plant pathogens. Plant Soil, 340, 505-520 (2011).

41. Plou, F. J. et al. Analysis of Tween 80 as an esterase/lipase substrate for lipolytic activity assay. Biotechnol. Tech, 12 (3), 183-186 (1998).

42. Rehman, H. U., Qader, S. A. U., Aman, A. \& Polygalacturonase Production of pectin depolymerising enzyme from Bacillus licheniformis KIBGE IB-21. Carbohydrate polymers, 90 (1), 387-391 (2012).

43. Robinson, R. J. et al. Endophytic bacterial community composition in wheat (Triticumaestivum) is determined by plant tissue type, developmental stage and soil nutrient availability. Plant and soil, 405 (1-2), 381-396 (2016).

44. Rosenblueth, M. \& Martinez-Romero, E. Bacterial Endophytes and Their Interactions with Hosts. Mol. Plant Microbe Interact, 19, 827-837 (2006).

45. Ruiza, D., Agaras, B., de-Werrab, P., Wall, L. G. \& Valverde, C. Characterization and Screening of Plant Probiotic Traits of Bacteria Isolated from Rice Seeds Cultivated in Argentina. Journal of Microbiology, 49 (6), 902-912 (2011).

46. Saha, B. C. Production, purification and properties of xylanase from a newly isolated Fusarium proliferatum. Process Biochem, 37 (11), 1279-1284 (2002). 
47. Sahu, M. K., Sivakumar, K. \& Kannan, L. Degradation of organic matters by the extra-cellular enzymes of actinomycetes isolated from the sediments and molluscs of the Vellar estuary. J. Aqua. Biol, 20 (2), 142-144 (2005).

48. SaiPrasad, J., Aswini, K., Sharma, P., Gond, S. \& Suman, A. A. Novel Wheat Matrix Medium (WMM) For Rapid Isolation of Hydrolytic Enzyme Producing Bacterial Seed Endophytes. Int.J.Curr.Microbiol.App.Sci, 9 (12), 2181-2197 (2020).

49. Schloss, P. D. et al. Introducing mothur: open-source, platform-independent, community-supported software for describing and comparing microbial communities. Applied and environmental microbiology, 75 (23), 7537-7541 (2009).

50. Schwyn, B. \& Neilands, J. B. Universal chemical assay for the detection and determination of siderophores. Analytical biochemistry, 160 (1), 47-56 (1987).

51. Sijam, K. \& Dikin, A. Biochemical and physiological characterization of Burkholderia cepacia as biological control agent. Int J Agric Biol, 7 (3), 385-388 (2005).

52. Smibert, R. M. \& Krieg, N. R. Phenotypic characterization. In: Gerhardt P, Murray RGE, Wood WA, Krieg NR (eds) Methods for general and molecular bacteriology. ASM, Washington, 607-654(1994).

53. Tamura, K., Dudley, J., Nei, M. \& Kumar, S. MEGA4: Molecular Evolutionary Genetics Analysis (MEGA) Software Version 4.0. Mol. Biol. Evol, 24 (8), 1596-1599 (2007).

54. Thomas, P. Intense association of non-culturable endophytic bacteria with antibiotic-cleansed in vitro watermelon and their activation in degenerating cultures. Plant cell reports, 30 (12), 2313-2325 (2011).

55. Thomas, P. \& Reddy, K. M. Microscopic elucidation of abundant endophytic bacteria colonizing the cell wall-plasma membrane peri-space in the shoot-tip tissue of banana.AoB Plants, 5 (2013).

56. Tilak, K. V. B. R. et al. Diversity of plant growth and soil health supporting bacteria.Current science,136-150(2005).

57. Trethowan, R. An analysis of wheat yield and adaptation in India. Field Crops Research, 219, 192-213 (2018).

58. Truyens, S. et al. The effect of long-term $\mathrm{Cd}$ and $\mathrm{Ni}$ exposure on seed endophytes of Agrostiscapillaris and their potential application in phytoremediation of metal-contaminated soils. International journal of phytoremediation, 16 (7-8), 643659 (2014).

59. Truyens, S., Weyens, N., Cuypers, A. \& Vangronsveld, J. Bacterial seed endophytes: genera, vertical transmission and interaction with plants. Environ. Microbiol. Rep, 7, 40-50 (2015).

60. Tsuchida, O. et al. An alkaline proteinase of an alkalophilicBacillus sp. Curr. Microbiol, 14 (1), 7-12 (1986).

61. Van-den, B. F., Paveley, N. D., Bingham, I. J. \& van den Bosch, F. Physiological traits determining yield tolerance of wheat to foliar diseases. Phytopathology, 107 (12), 1468-1478 (2017).

62. Verma, P., Yadav, A. J., Kazy, S. K., Saxena, A. K. \& Suman, A. Evaluating the diversity and phylogeny of plant growth promoting bacteria associated with wheat (Triticum aestivum) growing in central zone of India. Int. J. Curr. Microbiol. App. Sci, 3 (5), 432-447 (2014).

63. Verma et al. Elucidating the diversity and plant growth promoting attributes of wheat (Triticumaestivum) associated acidotolerant bacteria from southern hills zone of India". Indian Journal of Life Sciences, 10 (2), 219-227 (2013).

64. Vyas, P., Rahi, P. \& Gulati, A. Stress tolerance and genetic variability of phosphate-solubilizing fluorescent Pseudomonas from the cold deserts of the trans-Himalayas. Microb. Ecol, 58 (2), 425-434 (2009).

65. White, J. F. et al. Evidence for widespread microbivory of endophytic bacteria in roots of vascular plants through oxidative degradation in root cell periplasmic spaces. In PGPR amelioration in sustainable agriculture (pp.167193).Woodhead Publishing(2019).

66. Xu, M. et al. Bacterial community compositions of tomato (Lycopersicumesculentum Mill.) seeds and plant growth promoting activity of ACC deaminase producing Bacillus subtilis (HYT-12-1) on tomato seedlings. World J. Microbiol. Biotechnol, 30, 835-845 (2014).

\section{Figures}

Page $17 / 21$ 


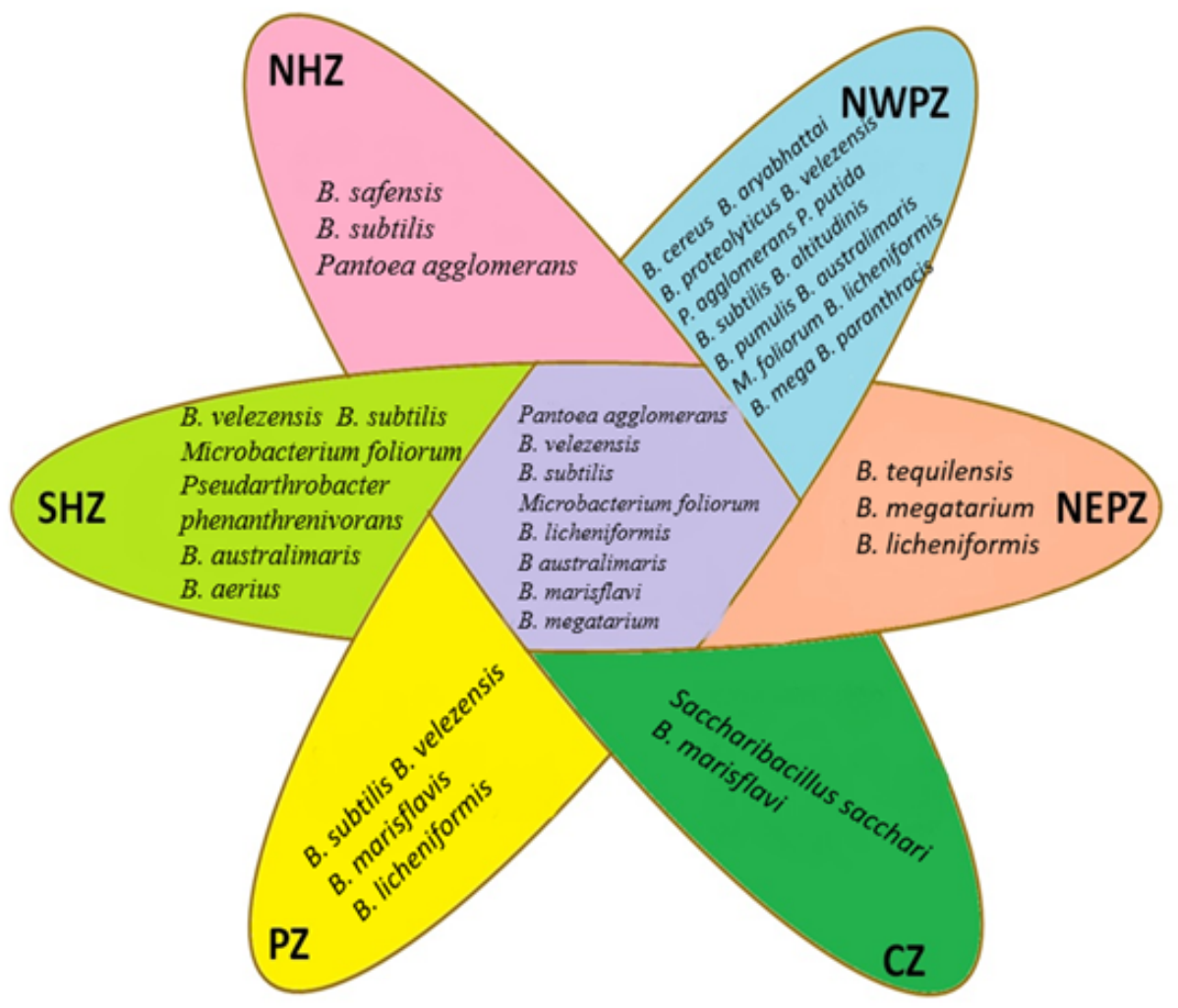

\section{Figure 1}

Niche specific and common endophytic bacterial species isolated from different zones 


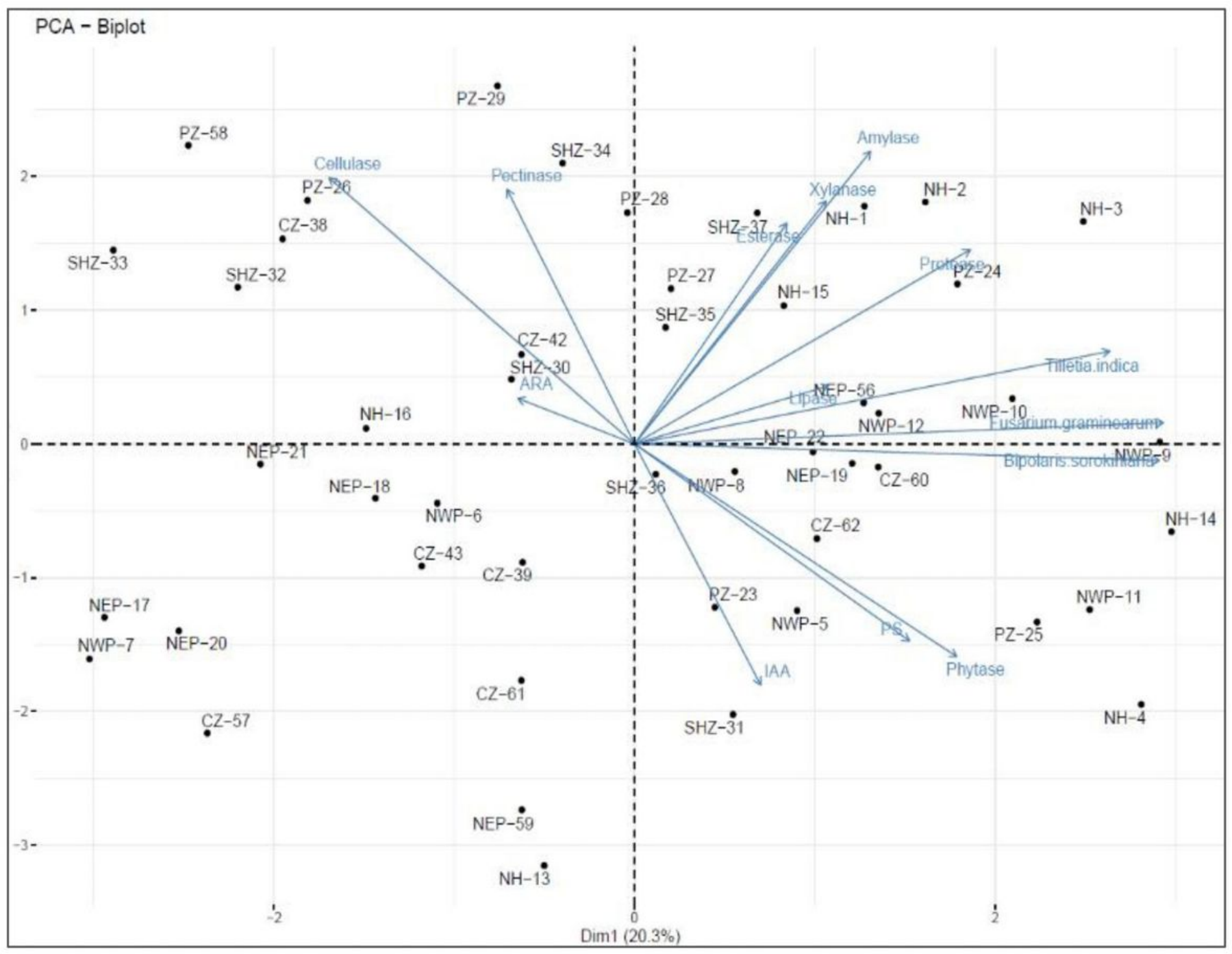

Figure 2

(a) Principal coordinate analysis of the different attributes, Biplot showing relationship PGP, lytic enzymes and Biocontrol of bacterial isolates, Component 1 and Component 2 accounted for $22.9 \%$ and for $14.5 \%$ of the total variation, respectively. (b) Variable PCA showing relationship between different activities viz., PGP, lytic enzymes and Biocontrol of bacterial isolates in total variation covered by component $1(22.9 \%$ and component $2(14.5 \%)$. 


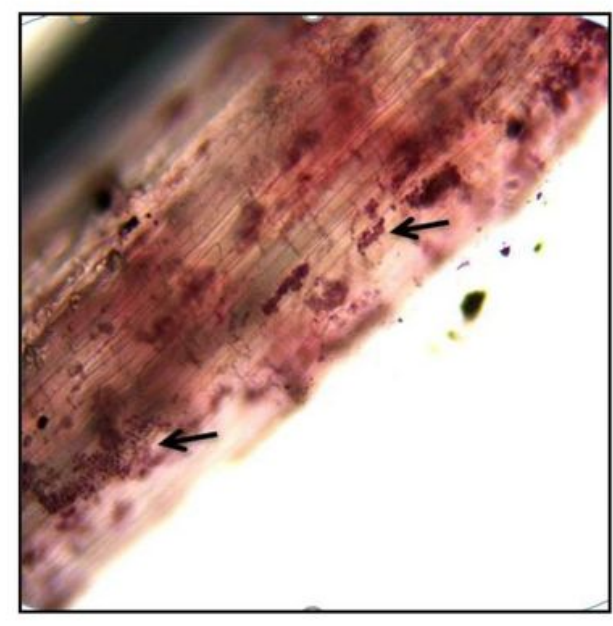

(a)

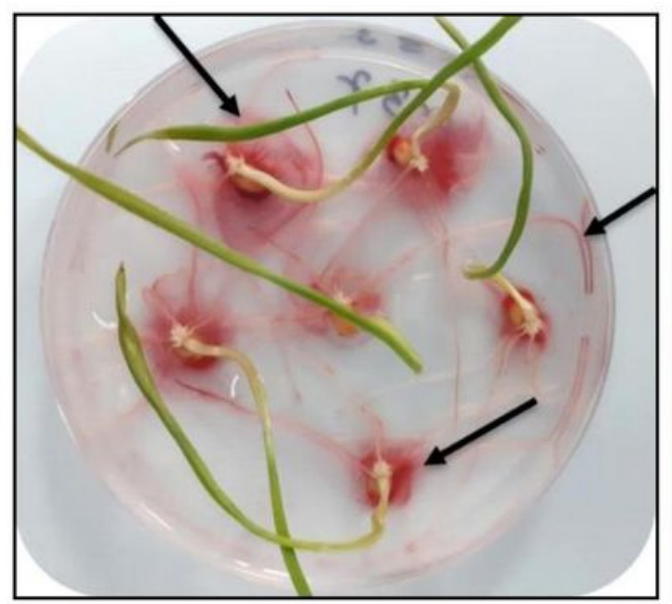

(d)

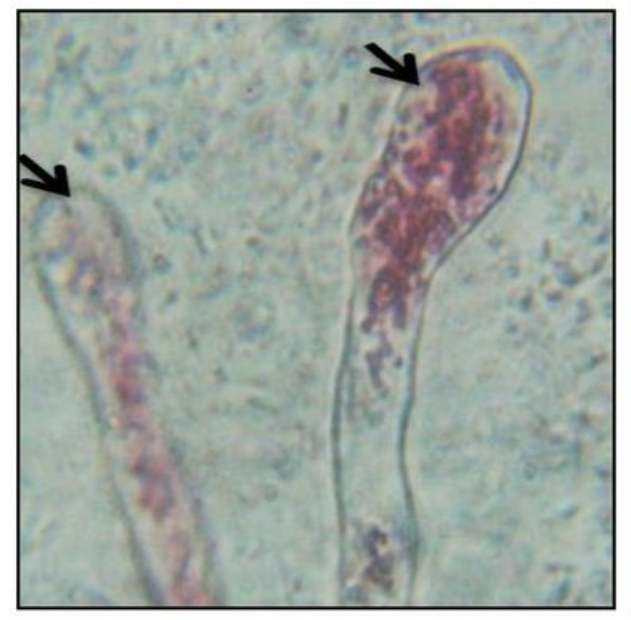

(b)

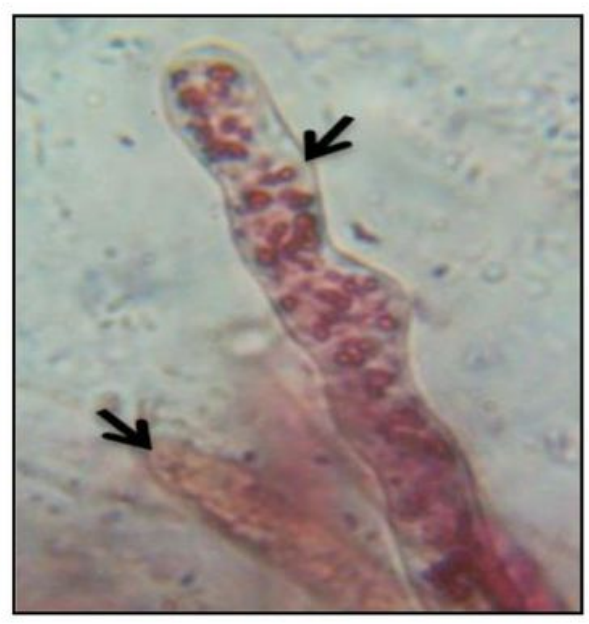

(c)

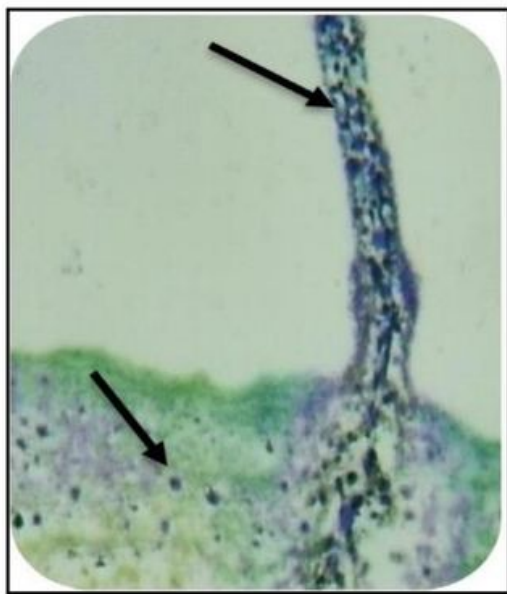

(e)

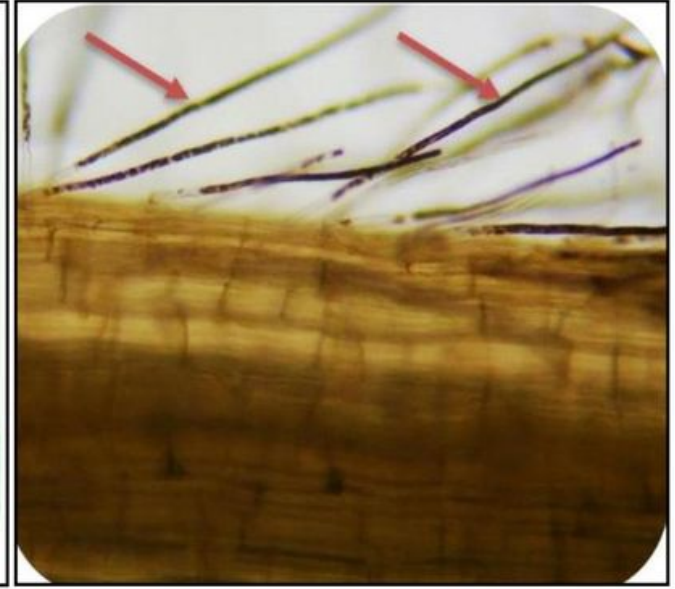

(f)

\section{Figure 3}

Colonization of bacterial seed endophytes in wheat seedlings evident from TTC and H2O2 treatment. a-main roots (TTC); broot hair tips (TTC); c-root hairs (TTC); d-seedlings treated with TTC; e-main roots (H2O2)and f-root hairs (H2O2). 


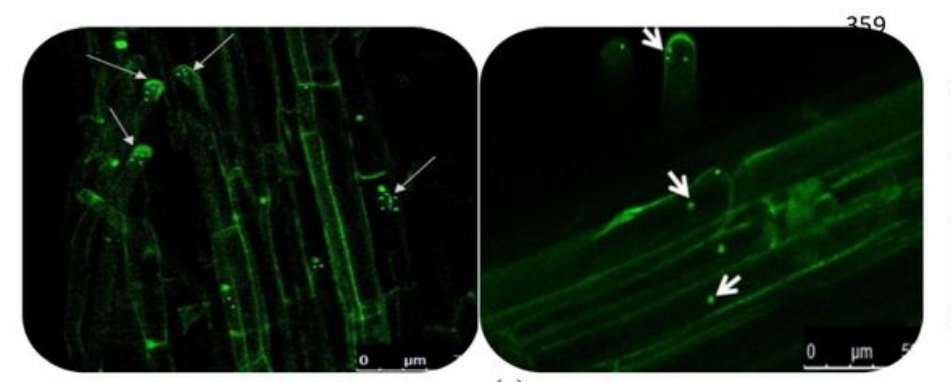

(a)

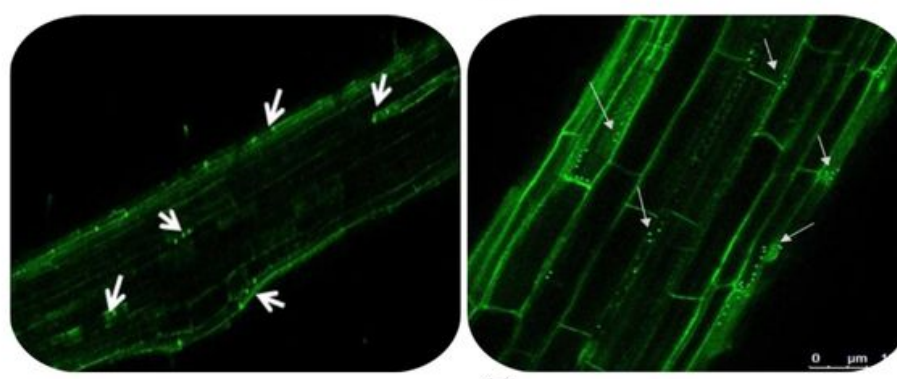

(c)

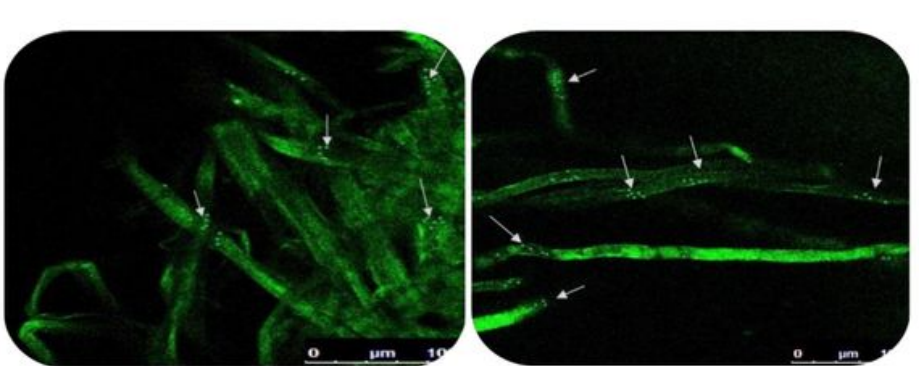

(b)

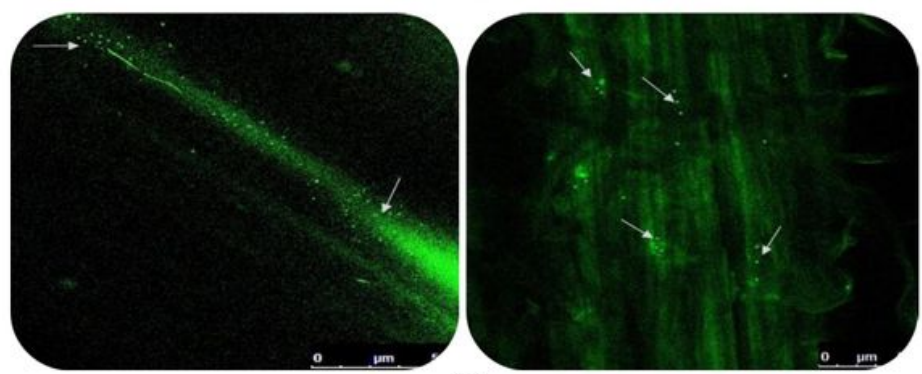

(d)

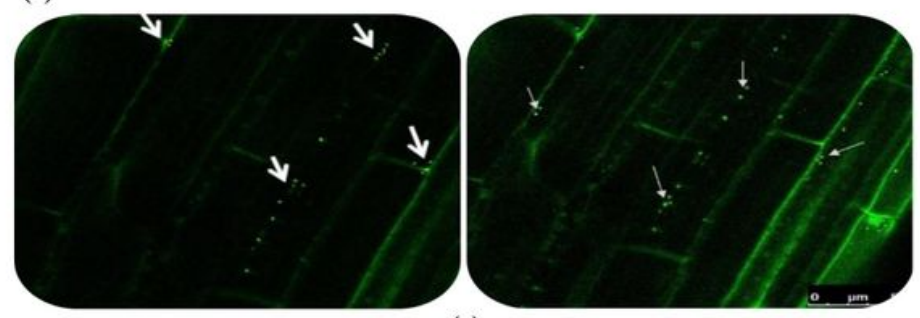

(e)

\section{Figure 4}

GFP tagged endophytes tracking in 15 days wheat seedlings under hydroponic condition using confocal microscopy. a. Colonization in root tips; b. Colonization in root hairs; c. Colonization in main roots; $d$. Colonization in cross sectioning of stem; e. Colonization in leaf of wheat plant.

\section{Supplementary Files}

This is a list of supplementary files associated with this preprint. Click to download.

- SupplementaryInformation.docx 